\title{
Happiness Index for Human Resource Management Practitioners Associated with the Professional Body
}

\author{
Molefe Jonathan Maleka, Ilze Swarts, Magdeline Mmako \\ Tshwane University of Technology, South Africa \\ Malekam@tuut.ac.za, SwartsI@tut.ac.za, MmakoMM@tut.ac.za
}

\begin{abstract}
The study explored the perceptions of human resource management (HRM) practitioners in South Africa, using the following happiness dimensions: positive emotions, job-related wellbeing, affective commitment, employee engagement and distributive justice. The research approach was quantitative, and the research design was descriptive and longitudinal (i.e. over a two-year period). The convenience sampling technique was used to select participants. In 2016, the sample size was 204, and in 2017, the sample size was 76. The data were collected at the conventions hosted by the Institute of People Management (IPM). The major findings were that the majority of the participants were females, were employed on a full-time basis, had degrees, earned R40 000 and above, and were not unionized. Participants rated the positive emotions negatively, suggesting that they were disaffected with their remuneration, and they rated the job-related wellbeing, affective commitment, employee engagement and distributive justice items positively. The implication of this study for policymakers is that they must review their remuneration policy and practices. The implication for managers is that they might struggle to keep HRM practitioners effective, motivated, and having cordial relationships.
\end{abstract}

Keywords: Affective commitment, employee engagement, job-related wellbeing, distributive justice, positive emotions

\section{Introduction}

Happiness is a positive emotion comprising positive emotions, job-related wellbeing, affective commitment, employee engagement and distributive justice as dimensions (Fisher, 2010). Scholars conducting research in the workplace found that happy employees are productive (Armenta, Fritz \& Lyubomirsky, 2017; Bakhtiar, Bahrami, Keyvanara \& Kalantari, 2009; De Neve, Diener, Tay \& Xuereb, 2013; Lyubomirsky King \& Diener, 2005; Wesarat, Yazam, \& Halim, 2014; Zarei \& Hughgooyan, 2011). The challenges for HRM practitioners are two-fold- they are both implementers and recipients of human resource practices (Pereira \& Fontinha, 2016). As the first and largest HR professional body in Africa, the IPM is recognized by the South African Qualifications Authority (SAQA). The first branch of the IPM was established in August 1945, as an affiliate of the British IPM, and since then, the organization has produced numerous HR professionals, who have effectively managed the evolution of the HR profession in South Africa (A History of People Development, 2013). The IPM hosts an annual gathering of HR industry thought leaders, where practitioners can gain valuable insight into various topical issues presented by experts. At these gatherings, practitioners can keep up to date with the business trends and challenges facing South African organizations. Data about the happiness index dimensions from the HRM practitioners were collected in 2016 and 2017 at the IPM-hosted conventions at Monte Casino, Gauteng, South Africa. Thus far, there is no study that has developed an HRM practitioners' happiness index in South Africa that is affiliated to a professional body. This study addressed this gap by developing an HRM index, using validated and reliable scales (i.e. positive emotions, job-related wellbeing, affective commitment, employee engagement and distributive justice).

\section{Theoretical Framework}

Happiness has two components, affective and cognitive. The affective component deals with employees' emotions (Fors \& Kulin, 2016; Ryan \& Deci, 2001) and the cognitive component includes virtue, morality, being truthful to self, meaning, and growth (Ryff \& Singer, 2008). Employers make efforts to keep employees happy, in order to enhance employment relationships (Rodriques \& Sanz, 2013; Roehling, Cavanaugh, Moynihan \& Boswell, 2000; Weserat, Yazam \& Halim, 2014), and to retain competent and productive employees (De Neve et al., 2013). Pryce-Jones and Lindsay (2014) suggested that happy and effective employees have a positive mindset, perform optimally, and help employers to achieve production, sales and 
profit targets. In this study, the dimensions of happiness index discussed are positive emotions, job-related wellbeing, affective commitment, employee engagement and distributive justice.

Positive Emotions: A positive emotion is an emotive state of joy, being inspired and grateful (Frederickson \& Kurt, 2011; Kuppens, Realo \& Diener, 2008; Shahrabani, Benzion, Rosenbiom \& Shavit, 2012; Stahl, 2016; Zizek, Mulej \& Milfelner, 2017). Employees experience positive emotions when they interact with other employees, and when they are allocated resources (Xanthopoulou, Bakker \& Fischbach, 2013). In this study, resources refer to remuneration. Research consistently found that no difference in positive emotions of high and low self-compassion employees (Choi, Lee \& Lee's, 2014) and dysphonic and non-dysphonic groups watching a movie (McMakin, Santiago \& Shirk, 2009).

Job-Related Wellbeing: Another happiness index dimension with almost the same definition as positive emotions is job-related well-being. However, it is related to energy, inspiration, fulfilment and excitement (Bakker \& Oerlemans, 2011; Keeman, Naswall, Malinen \& Kuntz, 2017; Kirsten, Van der Walt \& Viljoen, 2009; Rodríguez \& Sanz, 2013), which leads to organizational success (Page \& Vella-Brodrick, 2009). The study conducted by Warr and Inceoglu (2017), which comprised of two groups, found no significant differences between them in relation to wellbeing.

Affective Commitment: A happiness index dimension that may ultimately enhance employees' loyalty to organizations is known as affective commitment (Abdullah, Ling. \& Peng, 2016; Ghaffaripour, 2015; Ha \& Ha, 2015; Hechl, 2017; Lambert, Kim, Kelly \& Hogan, 2013; Simons \& Buitendach, 2013; Toga, Qwabe \& Mjoli, 2014). It is suggested that employees who are affectively committed to their organizations are productive, do not take leave on a regular basis, and do not resign from their organizations (Akar, 2018). Studies in India and the Orange County Interscholastic Athletic Association (OCIAA) in the United States of America found no differences in the affective commitment scores of men and women employees (Sharma, 2015; Rainayee \& Zaffar, 2013; Voloshin, 2017).

Employee Engagement: A happiness index dimension that is closely related to job-related wellbeing is employee engagement (Albrecht, 2012). Employee engagement refers to employees' cognitive (Moradi, Jafari \& Abedi, 2005; Shuck \& Wollard, 2010) and emotional attachment to their roles (Bakker \& Schaufeli, 2014; Rich, Lepine \& Crawford, 2010), which leads to an employee being motivated to do more at work (Joo \& Lee, 2017). One element that distinguishes it from positive emotions and job-related well-being is that it is related to successful implementation of the organization's strategy (Maleka, Schultz, Van Hoek, Dachapalli \& Ragadu, 2017), especially when union members are involved (Maleka, 2018; Nienaber \& Martins, 2016). The empirical research by Wilson (2009) found no difference between the participants with supervisory job titles and non-supervisors. A recent study conducted by Vorina, Simonic and Vlasova (2017), found that there is no difference between gender and employee engagement. Similarly, Tshilongamulenzhe and Takawira (2015) found that male and female employees demonstrated almost equal levels of engagement to their work.

Distributive Justice: Whereas the other happiness index dimensions discussed above are about emotions and strategy implementation, distributive justice is" the perceived fairness of outcome one receives" (Ha \& Ha, 2015, p. 109) based on income (Bayarcelik \& Findikli, 2016; Ohana \& Meyer, 2016). and job (Demir, 2016). Employees who deemed work practices to be fair were happy, and performed optimally (Kalay \& Turkey, 2016; Nasurdin \& Khuan, 2011). Hataman, Fardid and Kavosi (2013) study found no differences in the distributive justice scores of nurses in general and speciality in Shiraz's hospitals. Distributive justice originates from Adams' (1965) equity theory. Akram, Qamar, Answer, Malik and UI Haq (2015) compared organizational justice and commitment in public universities in Pakistan, and found that there is no statistically significant difference between the scores of male and female university teachers. In another study, Brienza and Bobocel (2017) found that there was no statistically significant difference between the distributive justice scores of younger and older employees. However, Mendryk's (2017) study on the impact of procedural and distributive justice on the organizational commitment of employees of different ages found a difference in the distributive justice scores of younger and older age groups. The literature clearly shows the paucity of studies that measure the happiness dimensions' index of HRM practitioners attending a professional body convention. Some of the previous research found no significant difference in terms of age (Brienza \& Bobocel, 2017) and gender (Vorina et al., 2017). The research methods used to achieve the study 
objective are discussed in the next section. The majority of the participants were permanently employed. This appears to suggest that their organizations invested in their skills development, as the cost (i.e. around R10 000.00) of their convention attendance included convention fees and accommodation.

\section{Methods}

The discussion in this section focuses on the research design, participants' biographical data, the research procedure, measuring instrument, and data analysis.

Research Design and Participants' Biographical Data: The research design was longitudinal (i.e. i.e. over a two-year period). The convenience sampling technique was used to select participants. As it can be observed from Table 1 below, in 2016, 250 questionnaires were printed and only 204 were completed, while 3 had missing information, and were therefore discarded. The majority of the participants were females (56.57\%), were employed on a permanent basis (96.47\%), had degrees and post-graduate qualifications (78.20\%), ranged in age from 35 to 65 (7.30\%), earned R40000 and above (62.24\%), and were not unionized (64.32\%). Seventy-six questionnaires were completed in 2017 and 200 questionnaires were distributed. The response rate was $39 \%$. The 2017 data revealed that $68.52 \%$ of the participants were females, $96.05 \%$ were employed on a permanent basis, had degrees and post-graduate qualifications (94.80\%), ranged in age from 35 to 65 (72.37\%), and earned R40000 and above (60.53\%). Almost sixty-seven percent (66.70\%) of the participants were not unionized.

Table 1: Biographical Data of Participants

\begin{tabular}{|c|c|c|c|c|}
\hline Variables & 2016 frequencies & 2016 percentages & 2017 frequencies & 2017 percentages \\
\hline \multirow[t]{2}{*}{ Gender } & Male $(\mathrm{n}=86)$ & $43.43 \%$ & Male (n=24) & $31.57 \%$ \\
\hline & Female $(n=112)$ & $56.57 \%$ & Female $(n=52)$ & $68.52 \%$ \\
\hline \multirow[t]{2}{*}{$\begin{array}{l}\text { Employment } \\
\text { status }\end{array}$} & $\begin{array}{l}\text { Permanently } \\
\text { employed (n=191) }\end{array}$ & $96.47 \%$ & $\begin{array}{l}\text { Permanently } \\
\text { employed }(n=73)\end{array}$ & $96.05 \%$ \\
\hline & $\begin{array}{l}\text { Non-permanent } \\
\text { workers }(n=6)\end{array}$ & $3.03 \%$ & $\begin{array}{l}\text { Non-permanent } \\
\text { workers }(n=2)\end{array}$ & $2.63 \%$ \\
\hline \multirow[t]{6}{*}{ Education level } & Grade $12(n=0)$ & $0.00 \%$ & Grade $12(\mathrm{n}=0)$ & $1.30 \%$ \\
\hline & Certificate $(n=7)$ & $3.55 \%$ & Certificate $(n=1)$ & $2.60 \%$ \\
\hline & Diploma (n= 36) & $18.27 \%$ & Diploma (n=16) & $21.10 \%$ \\
\hline & Degree $(n=80)$ & $40.61 \%$ & Degree $(n=31)$ & $40.80 \%$ \\
\hline & $\begin{array}{l}\text { Post-graduate }(n= \\
74)\end{array}$ & $37.56 \%$ & $\begin{array}{l}\text { Post graduate }(n= \\
24)\end{array}$ & $32.90 \%$ \\
\hline & Other $(n=0)$ & & Other $(n=1)$ & $1.30 \%$ \\
\hline \multirow[t]{2}{*}{ Age } & $18-34(n=41)$ & $20.70 \%$ & $18-24(\mathrm{n}=21)$ & $27.63 \%$ \\
\hline & $35-65(n=157)$ & $79.30 \%$ & $35-65(n=55)$ & $72.37 \%$ \\
\hline \multirow[t]{5}{*}{$\begin{array}{l}\text { Household } \\
\text { income }\end{array}$} & $\begin{array}{l}\text { Less than R10000 } \\
(n=3)\end{array}$ & $1.56 \%$ & $\begin{array}{l}\text { Less than R10000 } \\
(\mathrm{n}=0)\end{array}$ & $0.00 \%$ \\
\hline & $\begin{array}{l}\mathrm{R} 10000 \text { to } \mathrm{R} 19999 \\
(\mathrm{n}=10)\end{array}$ & $5.10 \%$ & $\begin{array}{l}\text { R10000 to R19999 } \\
(n=5)\end{array}$ & $6.58 \%$ \\
\hline & $\begin{array}{l}\mathrm{R} 20000 \text { to } \mathrm{R} 29999 \\
(\mathrm{n}=29)\end{array}$ & $14.80 \%$ & $\begin{array}{l}\mathrm{R} 20000 \text { to } \mathrm{R} 29999 \\
(\mathrm{n}=14)\end{array}$ & $18.42 \%$ \\
\hline & $\begin{array}{l}\text { R30000 to R39999 } \\
(n=32)\end{array}$ & $16.32 \%$ & $\begin{array}{l}\text { R30000 to R39999 } \\
(n=11)\end{array}$ & $14.47 \%$ \\
\hline & $\begin{array}{l}\text { R40000 and above } \\
(n=122)\end{array}$ & $62.24 \%$ & $\begin{array}{l}\text { R40000 and above } \\
(n=46)\end{array}$ & $60.53 \%$ \\
\hline Trade union & Yes $(n=71)$ & $35.67 \%$ & Yes $(n=24)$ & $31.58 \%$ \\
\hline membership & No $(n=128)$ & $64.32 \%$ & No $(n=52)$ & $68.42 \%$ \\
\hline
\end{tabular}

Procedure: Ethical clearance for this study was granted by Tshwane University of Technology (TUT). Content validity was achieved by presenting the research instrument to human resource department experts (Struwig \& Stead, 2013) at TUT. Once ethical clearance was granted, one of the researchers who attended the 
I feel a strong sense of belonging to my organization

When I am working, I forget everything around me

I feel happy when I am working intensively

Overall, the rewards I receive here are quite fair

I am rewarded fairly for the amount of effort I put in

I am rewarded fairly for the work that I have done

Cronbach's alphas 0.98
.81

.84

.93

.66

.66

The data presented in Table 3 show that the 2016 group had slightly higher positive emotions mean score $(M=3.84, S D=1.70)$ than the 2017 group $(M=3.73, S D=1.66)$. Since their mean scores were below 4 , it can be argued that HRM practitioners were not happy with their remuneration. Participants rated other happiness index dimensions (i.e. job-related wellbeing, affective commitment, employee engagement and distributive justice) positively, since their mean scores were above 4 .

Table 3: Happiness Dimensions Scores

\begin{tabular}{lllllll}
\hline $\begin{array}{l}\text { HRM practitioner } \\
\text { groups }\end{array}$ & $\begin{array}{l}\text { Positive } \\
\text { emotions }\end{array}$ & $\begin{array}{l}\text { Job-related } \\
\text { wellbeing }\end{array}$ & $\begin{array}{l}\text { Affective } \\
\text { commitment }\end{array}$ & $\begin{array}{l}\text { Employee } \\
\text { Engagement }\end{array}$ & $\begin{array}{l}\text { Distributive } \\
\text { justice }\end{array}$ \\
\hline 2016 & Mean & 3.84 & 4.70 & 4.46 & 4.79 & 4.12 \\
& $\mathrm{~N}$ & 181 & 184 & 185 & 186 & 189 \\
& Std. Deviation & 1.70 & 1.72 & 1.71 & 1.50 & 1.63 \\
2017 & Mean & 3.44 & 4.52 & 4.28 & 4.59 & 3.87 \\
& N & 72 & 73 & 75 & 73 & 72 \\
\multirow{2}{*}{ Total } & Std. Deviation & 1.51 & 1.36 & 1.60 & 1.28 & 4.05 \\
& Mean & 3.73 & 4.65 & 4.41 & 4.73 & 261 \\
& N & 253 & 257 & 260 & 259 & 1.56 \\
\hline
\end{tabular}

Prior to conducting the statistical difference test, the researchers conducted a normality test using the skewness test, and found that the skewness values were less than +-1 (Leech, Barrett \& Morgan, 2015). The P$\mathrm{P}$ plots centred on the diagonal straight lines (Pallant, 2016) of the happiness index dimensions. These statistics suggested that the data were normally distributed. Based on these statistics, the researchers deemed the T-Test an appropriate statistic to determine if there are statistically significant differences in the happiness index dimensions. The data displayed in Table 4 below showed that there is no statistically significant difference in the happiness index dimension means scores of two groups (i.e. HRM practitioners who attended the 2016 and 2017 IPM conventions). Consistent with previous research in this area, the data in this study revealed that HRM practitioners rated positive emotions (i.e. remuneration items) negatively (Maleka, Mmako \& Swarts, 2017). The results were surprising because the majority of the respondents earned R40 000 and above.

Table 4: T-Test for Happiness Index Dimensions

\begin{tabular}{llllll}
\hline Happiness index dimensions & F & Sig. & T & DF & Sig. (2-tailed) \\
\hline Positive emotions & 1.97 & .16 & 1.86 & 146.44 & .07 \\
Job-related wellbeing & 4.78 & .03 & .92 & 165.58 & .36 \\
Affective commitment & .07 & .80 & .78 & 258 & .44 \\
Employee Engagement & 1.89 & .17 & 1.00 & 257 & .32 \\
Distributive justice & 4.62 & .03 & 1.26 & 154.41 & .21 \\
\hline
\end{tabular}




\section{Discussion:}

The trend looked similar to the living wage study that was conducted on low-income workers who earned between R1500 to R4500 (Maleka, 2016). This might have negative managerial implications for organizations, as other scholars have found that unhappy employees are not effective (Rodriques \& Sanz, 2013; Weserat et al., 2014), motivated (De Neve et al., 2013), and they end-up having bellicose or adversarial relationships with managers (Roehling et al., 2000). The data showed that most participants were aged 35 years and above. This suggested that most of the HRM practitioners were not millennials, as millennials are aged between 18 and 24 years (Migacz \& Petrick, 2018). Most of the participants were not unionized and had tertiary qualifications (undergraduate and postgraduate). International scholars also found that educated employees are not unionized, and that management plays a role in discouraging the unionization of employees (Evans, Pyman \& Byford, 2016). Prior to this study, there was no happiness index for HRM practitioners in South Africa, using the dimensions considered in this study. The happiness index dimensions were developed using EFA (Refer to Table 2). Since the happiness index dimensions Cronbach's alphas were above 0,7 , the cut-off suggested by Maree (2016), it can be argued that they were reliable.

Even though 2016 groups were happier than those who attended the 2017 convention, there were statistically significant differences amongst the happiness index dimensions. In terms of policy-makers, this study suggested that they should review the remuneration practices for HRM practitioners. This study had several limitations. Firstly, there was limited literature measuring the statistically significant differences of HRM practitioners attending a professional body convention. Therefore, in address the aim of the study, the researchers relied on studies that measured biographical differences (Brienza \& Bobocel, 2017; Choi, Lee \& Lee, 2014; Rainayee \& Zaffar, 2013; Sharma, 2015; Tshilongamulenzhe \& Takawira, 2015; Voloshin, 2017; Vorina et al., 2017), other groups, such as dysphonic and non-dysphonic (McMakin et al., 2009), and supervisors and non-supervisors (Wilson, 2009). Secondly, the sample sizes were very small, data were collected using the non-probability sampling technique, and the researchers did not collect data from HRM practitioners attending other professional bodies' conventions in South Africa. Consequently, the study findings cannot be generalized to all HRM practitioners in South Africa. Despite the limitations of this study, it contributed to the body of knowledge by developing a happiness index for HRM practitioners using reliable and valid measuring scales.

Future research should be qualitative, in order to further explore the subtle narratives of why HRM practitioners have negative perceptions of their remuneration. Using a qualitative approach, an in-depth investigation should be conducted as to why employees who earn R40 000 and above are still unhappy with their salaries. Future research should focus on millennials and be extended to include other HRM professional bodies in South Africa, as well as other African countries. A larger and more representative sample should be selected from the IPM database, and an online survey should be conducted. As indicated by Leedy and Ormrod (2015) and Bless et al. (2013), this will help to achieve external validity. It is also recommended that organizations do the following in order to enhance employees' happiness: 1) review and benchmark remuneration practices; 2) investigate and implement best HRM practices and non-remuneration practices that will keep employees excited, energized and inspired; 3 ) engage employees so that they are invigorated and work intensely to be productive; 4) treat HRM practitioners well, so that they are affectively committed to the organization; and 5) implement fair rewards practices.

Acknowledgement: The authors are grateful to Professor Stuart Carr from Massey University for being an excellent mentor and for the financial assistance from TUT's Research and Innovation. Prof. Carr is the founding member of Global Living Organizational Wage (GLOW).

\section{References}

Abdullah, A. G. K., Ling, Y. \& Peng, C. (2016). Workplace happiness, transformational leadership and affective commitment. International Conference on Social Sciences and Humanities (SOSHUM), Kota Kingbalu, Sabah.

Adams, J. S. (1965). Inequity in social exchange. In I. Berkowitz (Ed.). Advances in experimental social psychology, 2, 367-299. 
Allen, N. J. \& Meyer, J. P. (1990). Affective, continuance and normative commitment to the organization: An examination of construct validity. Journal of Vocational Behavior, 49(3), 252-276.

A history of people development. (2013). Mail \& Guardian, 8 November.

Akar, H. (2018). The relationships between quality of work life, school alienation, burnout, affective commitment and organizational citizenship: a study on teachers. European Journal of Educational Research, 7(2), 169-180.

Akram, M., Qamar, A. H., Answer, M., Malik, M. I. \& UI Haq, A. (2015). Comparing the organizational justice and commitment in public universities in Pakistan, (4), 71-84.

Albrecht, S. L. (2012). The influence of job, team, and organizational level resources on employee well-being, engagement, commitment and extra-role performance: Test of a model. International Journal of Manpower, 33(7), 840-853.

Armenta, C. N., Fritz, M. M. \& Lyubomirsky, S. (2017). Functions of positive emotions: gratitude as a motivator of self-improvement and positive change. Emotion Review, 9(3), 183-190.

Bakhtiar, N. H. A., Bahrami, S., Keyvanara, M. \& Kalantari, M. (2009). Studying the happiness level among staff at Isfahan Medical University, Iran, Labor Health, 3, 5-11.

Bakker, A. B. \& Demerouti, E. (2008). Towards a model of work engagement. Career Development International, 13(3), 209-223.

Bakker, A. B., Schaufeli, W. B. (2014). Employee engagement. In Y. Feeney \& P. Flood. (Eds.), Organizational Behavior volume of Blackwell Encyclopedia of Management.

Bakker, A. B. \& Oerlemans, W. (2011). Subjective wellbeing, in Handbook of Positive Organizational Scholarship, 178-189.

Bayarcelik, E. B. \& Afakan Findikli, M. (2016). The mediating effect of job satisfaction on the relationship between organizational justice perception and intention to leave. 12th International Strategic Management Conference, ISMC, Antalya, Turkey. Procedia-Social and Behavioral Sciences, 235, 403411.

Bless, C., Higson-Smith, C. \& Sithole, S. L. (2013). Fundamentals of social research methods: An African perspective. Cape Town: Juta \& Company Ltd.

Brienza, J. P. \& Bobocel, D. R. (2017). Employee age alters the effects of justice on emotional exhaustion and organizational deviance. Frontiers in Psychology, 6, 1-15.

Choi, Y. M., Lee, D. \& Lee, H. (2014). The effect of self-compassion on emotions when experiencing a sense of inferiority across comparison situations. Counselling and Guidance WCPCG. Procedia -Social and Behavioral Sciences, 114, 949-953.

Demir, K. (2016). Relations between teachers: Organizational justice perceptions, organizational commitment, and job behaviour in the school: a meta-analysis. International Journal of Human Sciences, 13(1), 1409-1417.

De Neve, J. E., Diener, E., Tay, L. \& Xuereb, C. (2013). The objective benefits of subjective well-being. In J. Helliwell, R. Layard, \& J. Sachs (Eds.), World happiness report 2013, 54-79. New York, NY: UN Sustainable Development Solutions Network.

Evans, S. Pyman, A. \& Byford, I. (2016). What are the consequences of a managerial approach to union renewal for union behaviour? A case study of USDAW. Employee Relations, 39(1), 2-18.

Field, A. (2013). Discovering Statistics using IBM SPSS Statistics. London: Sage Publications.

Fisher, C. D. (2010). Happiness at work. International Journal of Management Reviews, 12, 384-412.

Fors, F. \& Kulin, J. (2016). Bringing affect back in: Measuring and comparing subjective well-being across countries. Social Indicators Research, 127(1), 323-339.

Frederickson, B. L. \& Kurt, L. E. (2011). Cultivating positive emotions to enhance human flourishing. In S.I. Donaldson, Czikszenthmihalyi, M. \& Nakamura, J. (Eds.), Applied Positive Psychology: Improving everyday life, health, schools, work, and society (35-47). New York: Routledge.

Ghaffaripour, S. (2015). Prediction of affective organizational commitment based on employee characteristics and psychological factors among oil personnel. International Journal of Management Business and Residence, 5(4), 337-350.

Ha, J. \& Ha, J. (2015). Organizational justice-affective commitment in a team sports setting: The moderating effect of group cohesion. Journal of Management, 21(1), 107-124.

Hataman, N., Fardid, M. \& Kavosi, Z. (2013). Perceptions of organizational justice among nurses working in university hospitals of Shiraz: A comparison between general and speciality settings. Nurses Midwifery Studies, 2(4), 77-82. 
Hechl, C. (2017). Affective commitment to organizations: A comparative study of reverse mentoring versus traditional mentoring among millennials. Binus Business Review, 8(2), 157-165.

Joo, B. \& Lee, L. (2017). Workplace happiness: Work engagement, career satisfaction, and subjective wellbeing. Evidence-based Human Resource Management: A Global Forum for Empirical Scholarship, 5(2), 206-221.

Kalay, F. \& Turkey, V. (2016). The Impact of Organizational Justice on Employee Performance: A Survey in Turkey and Turkish Context. International Journal of Human Resource Studies, 6(1), 1-20.

Keeman, A., Naswall, K., Malinen, S. \& Kuntz, J. (2017). Employee well-being: Evaluating a wellbeing intervention in two settings, 4, 505.

Kirsten, T. J., Van der Walt, H. L. \& Viljoen, J. T. (2009). Health, well-being and wellness: An anthropological eco-systematic approach. Journal of Interdisciplinary Health Science, 14(1), 1-7.

Kuppens, P., Realo, A. \& Diener, E. (2008). The role of positive and negative emotions in life satisfaction judgement across nations. Journal of Personality and Social Psychology, 95(1), 66-75.

Lambert, E. G., Kim, B., Kelly, T. \& Hogan, L. N. (2013). The association of affective and continuance commitment with correctional staff line satisfaction. The Social Science Journal, 50(1), 195-203.

Leech, N. L., Barrett, K. C. \& Morgan, G. A. (2015). IBM SPSS for intermediate statistics. Use and interpretation. New York, Routledge Francis and Taylor Group.

Leedy, P. D. \& Ormrod J. E. (2015). Practical research: Planning and design. (11th ed). Boston: Pearson Education Limited.

Lyubomirsky, S., King, L. \& Diener, E. (2005). The benefits of frequent positive affect: does happiness lead to success? Psychological Bulletin, 131, 803- 855.

McMakin, D. L., Santiago, C. D. \& Shirk, S. R. (2009). The time course of positive and negative emotion in Dysphonia. Journal of Positive Psychology, 4(2), 182-192.

Maleka, M. J. (2016). Narratives of employees visiting Tshwane mall who earn above and below an estimated living wage. GBATA conference proceedings in October 2016.

Maleka, M. J., Mmako, M. \& Swarts, I. (2017). Antecedents of affective commitment of human resource management practitioners attending a professional body convention, Journal of economics and behavioral sciences, 9(3), 121-132.

Maleka, M. J., Schultz, C. M., Van Hoek, L., Dachapalli, L. \& Ragadu, S. (2017). Measuring employee engagement of low-income workers either working at or visiting Marabastad Mall in the City of Tshwane Metropolitan Municipality. Journal of economics and behavioral sciences, 9(5), 74-82.

Maleka, M. J. (2018). The biographical and human resource management predictors of union membership engagement of low- and middle-income workers, Journal of economics and behavioral sciences, 10(1), 207-216.

Maree, K. (2016). First Steps in Research. (2nd ed). Pretoria: Van Schaik.

Melewar, T. C. \& Alwi, S. F. S. (2016). Corporate branding: Areas, arenas and approaches. London, United Kingdom: Routledge, Francis \& Taylor Group.

Mendryk, I. (2017). The impact of procedural and distributive justice upon the organizational commitment of age-diversified employees. Research Results, 108-114.

Moradi, J. J. E., Jafari, S. E. \& Abedi, M. R. (2005). Happiness and personality: a review study. Advances in cognitive science, $7(2), 60-71$.

Migacz, S. J. \& Petrick, J. F. (2018). Millennials: America's cash cow is not necessarily a herd. Journal of tourism futures, 4(1), 16-30.

Nasurdin, A. Z. \& Khuan, S. L. (2011). Organizational justice, age, and performance connection in Malaysia. International Journal of Commerce and Management, 21(3), 273-290.

Nienaber, H. \& Martins, N. (2016). Employee engagement in a South African context. Randburg: KR Publishing.

Ohana, M. \& Meyer, M. (2016). Distributive justice and affective commitment in non-profit organizations: which referent matters? Employee Relations, 38(6), 841-858.

Page, K. M. \& Vella-Brodrick, D. A. (2009). The 'what' 'why' and 'how' of employee well-being: A new model. Social Indicators Research, 90, 441-458.

Pallant, J. (2016). SPSS Survival Manual. A Step-by-step Guide to Data Analysis Using IBM SPSS (6th ed.). Crows' Nest: Allen \& Unwin. 
Pereira, V. S. \& Fontinha, R. (2016). An exploration of the role duality experienced by HR professionals as both implementers and recipients of HR practices: Evidence from Indian Railways. Human Resource Management, 55(1), 127-142.

Price, L. L. \& Mueller, C. W. (1986). Handbook of Organizational Measurement. Marshfield, MA: Pitman.

Pryce-Jones, J. \& Lindsay, J. (2014). What happiness at work is and how to use it? Industrial and Commercial Training, 46(3), 130-134.

Rainayee, R. A. \& Zaffar, S. (2013). Affective commitment: An empirical study of executive and non-executive bank employees. Global Journal of Management and Business Research Interdisciplinary, 13(7), 1.0.

Rich, B. L., Lepine, J. A. \& Crawford, E. R. (2010). Job engagement; antecedents and effects on job performance. Academy of Management Journal, 53(3), 617-635.

Rodríguez, M. A. \& Sanz, V. I. (2013). Happiness and well-being at work: A special issue introduction. Journal of Work and Organizational Psychology, 29, 95-97.

Roehling, M. V., Cavanaugh, M. A., Moynihan, L. M. \& Boswell, W. R. (2000). The nature of the new employment relationship: a content analysis of the practitioner and academic literature. Human Resource Management, 39, 305-320.

Ryan, R. M. \& Deci, E. L. (2001). On happiness and human potentials: a review of research on hedonic and eudaemonic well-being. Annual Review of Psychology, 52, 141-166.

Ryff, C. D. \& Singer, B. H. (2008). Know thyself and become what you are: a eudemonic approach to psychological well-being. Journal of Happiness Studies, 9, 13-39.

Schaufeli, W. B. \& Bakker, A. B. (2003). Utrecht Work Engagement Scale: Preliminary Manual. Utrecht: Occupational Health Psychology Unit, Utrecht University.

Shahrabani, S., Benzion, U., Rosenbiom, M. \& Shavit, T. (2012). Does moving from war zone change emotions and risk perceptions? A field study of Israel students. Judgement and Decision Making, 7(5), 609-678.

Sharma, P. (2015). Organizational commitment among faculty members in India: A study of public and private technical schools. Global Business and Organizational Excellence, July/August, 30-38.

Shuck, B. \& Wollard, K. (2010). Employee engagement and human resource development: A seminal review of the foundations. Human Resource Development Review, 9(1), 89-110.

Simons, J. \& Buitendach, J. (2013). Psychological capital, work engagement and organizational commitment amongst call centre employees in South Africa. Journal of Industrial Psychology, 39(2), 1-12.

Stahl, S. (2016). Evoking positive emotions through the use of virtual reality in relation to technique acceptance. The University of Twente.

Struwig, F. W. \& Stead, G. B. (2013). Research: Planning, Design and Reporting. 2nd ed. Boston: Pearson Education Limited.

Toga, R., Qwabe, N. P. \& Mjoli, T. Q. (2014). The impact of age and gender diversity on organizational commitment. Mediterranean Journal of Social Sciences, 5(1), 657-671.

Tshilongamulenzhe, M. C. \& Takawira, N. (2015). Examining gender influence on employees' work engagement within a South African University. Risk governance \& control, financial market \& institutions, 5(2), 110-119.

Van Katwyk, P. T., Fox, S., Spector, P. E. \& Kelloway, E. K. (2000). Using job-related well-being scale (JAWS) to investigate affective responses to work stressor. Journal of occupational health psychology, 5(2), 219230.

Vorina, A., Simonic, M. \& Vlasova, M. (2017). An analysis of the relationship between job satisfaction and employee engagement. Economic Themes, 55(2), 243-262.

Voloshin, G. V. (2017). Differences in organizational commitment between male and female coaches at the high school level. Doctorate of Education in Executive Leadership. St. John Fisher College.

Warr, P. \& Inceoglu, I. (2017). Work orientations, well-being and job content of self-employed and employed professionals. Work, employment and society, 1-20.

Wesarat, P., Yazam, M. S. \& Halim, A. M. A. (2014). A conceptual framework of happiness at the workplace. Asian Social Science, 11(2), 78-88.

Wilson, K. (2009). A survey of employee engagement. Columbia: University of Missouri.

Xanthopoulou, D., Bakker, A. B. \& Fischbach, A. (2013). Work engagement among employees facing emotional demands: the role of personal resources. Journal of Personnel Psychology, 12(2), 74-84.

Zarei, M. \& Hughgooyan, Z. (2011). Happiness in work and life. Qom Al-Hadi Publications.

Zizek, S. S., Mulej, M. \& Milfelner, B. (2017). Determinants of subjective emotional well-being and selfdetermination of employees: Slovene Case. Nase gospodarstvo/Our Economy, 63(4), 54-65. 